\title{
Induction of metallothioneins in the heavy metal resistant fungus Beauveria bassiana exposed to copper or cadmium
}

\author{
S. Kameo ${ }^{1 *}$, H. Iwahashi ${ }^{2}$, Y. Kojima ${ }^{3}$ and H. Satoh ${ }^{1}$ \\ ${ }^{1}$ Env. Health Sciences, Tohoku University Graduate School of Medicine, Sendai 980-8575, Japan \\ ${ }^{2}$ National Institute of Bioscience and Human-Technology, AIST, Tsukuba, Japan \\ ${ }^{3}$ Dept. Env. Med. and Inform., Hokkaido University, Sapporo, Japan
}

In our previous studies, we have isolated a copper-resistant (10 $\mathrm{mM}-\mathrm{Cu})$ fungus deuteromycotina Beauveria bassiana and examined that the fungus $B$. bassiana had additional resistances towards zinc, cadmium and lead. When $B$. bassiana was exposed to copper, copper was accumulated in the mycelia and a copper-metallothionein (MT) was induced. In contrast to vertebrate MTs, which bind different metal ions, fungal MTs were reported to contain exclusively copper ions, however, whether if other metal ions, such as cadmium, could induce a MT in fungal mycelia or not, still remain unknown. The purpose of this study are to investigate the inducibility of cadmium metallothionein in the fungus $B$. bassiana by cadmium exposure. This paper deals with the comparison of the chromatographic behavior and spectroscopic properties of cadmium-binding protein with copper-binding protein from this fungus, exposed to cadmium or copper. Upon exposure the fungus $B$. bassiana to cadmium $(0.5 \mathrm{mM})$, cadmium was incorporated and accumulated in the mycelia. Incorporated cadmium was eluted in low molecular weight region by the gel filtration. The elution profile showed very similar pattern to a copper-binding protein and revealed the existence of a low molecular weight, cadmium-binding protein. The absorption spectra which was lack of $280 \mathrm{~nm}$ showed a properties of metallothioneins and shoulder around $250 \mathrm{~nm}$ was typical of $\mathrm{Cd}$ (II)thiolate coordination. Upon removal of cadmium by acidification, the spectrum indicated a clear loss of the absorption shoulder. This feature can be interpreted as a manifestation of the cadmium thiolate cluster structure in the molecules. Exposure to cadmium may cause to induce a MT (class II type of MT) which might be family 8 according to a new classification in the fungus $B$. bassiana. It was suggested that MT could be induced in the fungus by not only copper but also cadmium exposure.

\section{Introduction}

Metallothioneins (MTs) are low molecular weight, unique cysteine rich metal-binding proteins [1-3], that were defined by several features [4-7]. MTs have been found from a wide variety of sources in eucaryotic organisms [7-10]. They are synthesized de novo upon exposure to various metal ions. In mammalian MTs, mainly zinc, cadmium, mercury and copper are natural parts of the protein structure [11-13].

The accumulation of heavy metals in fungi is a wellknown phenomenon [14]. Upon metal exposures, fungi synthesize two types of MTs, class II type of MT and phytochelatin (PC, class III type of MT). PC derivatives are not primary gene products, but are glutathione-related peptides $[4,15]$. Cellular resistance to heavy metal cytotoxicity in fungi is mainly mediated by the binding metal ions either to a MT or PC.

In contrast to vertebrate MTs, which bind different metal ions, fungal MTs were reported to contain exclusive copper ions. It was previously reported that incorporated copper in fungi was bound to low molecular weight ligands in the mycelia [16-18]. An ascomycete Neurospora crassa accumulated copper with a concomitant synthesis of copperbinding protein, consisted of a single polypeptide chain of 25 amino-acid residues, 7 cysteine residues lacking aromatic amino acid and binding exclusively copper [16-17]. From a mushroom, basidiomycete Agaricus bisporus, a copper-binding protein was also isolated and the chemical characterization of the protein was reported [18]. Both copper-binding proteins from Neurospora crassa and Agaricus bisporus were reported to belong to class II [5,16-18] of metallothioneins which would be family 8 according to a new classification [6-7]. It was also reported that exposure of Candida glabrata to copper salts stimulates formation of MTs, whereas exposure to cadmium salts PC derivatives were synthesized [19].

In our previous studies, we have isolated a copper-resistant (10 mM-Cu) fungus identified as Beauveria bassiana (Bals.) Vuillemin (Deuteromycotina: Hyphomycetes) and examined that the fungus $B$. bassiana had additional resistance towards zinc, cadmium and lead. When B. bassiana 
was exposed to copper, copper was accumulated in the mycelia and copper metallothionein was induced [20-21]. Whether if other metal ions, such as cadmium could induce a MTs or not, still remain unknown. The purpose of this study are to investigate the inducibility of a cadmium metallothionein in the fungus $B$. bassiana exposed to cadmium. This paper deals with the chromatographic behavior and spectroscopic properties of copper-binding protein or cadmium-binding protein from this fungus due to copper or cadmium exposure. The comparison of the properties of the copper-binding protein with the cadmium-binding protein from this fungus and inducibility of the MT-like cadmiumbinding protein were discussed.

\section{Materials and methods}

\section{Fungal strain and chemicals}

A fungus Beauveria bassiana were obtained by the screening on the high concentration $(6 \mathrm{mM})$ of copper containing medium [20-21]. Cupric chloride, cadmium chloride were products of Wako Pure Chemical Industries, LTD. Sephadex G-50 was purchased from Amersham Pharmacia Biotech. Trizma base (T1503) was obtained from Sigma. All other chemicals used in this experiment were of the analytical grade commercially available.

\section{Isolation of copper-binding or cadmium-binding proteins from the fungus Beauveria bassiana}

Beauveria bassiana was incubated in $1 \mathrm{~L}$ of liquid medium consisted of $0.2 \%$ (W/V) yeast extract, $2 \%$ peptone, $10 \%$ glucose. After 6 days of incubation, final $1 \mathrm{mM}-\mathrm{Cu}$ of cupric chloride or final $0.5 \mathrm{mM}-\mathrm{Cd}$ of cadmium chloride was administrated to the medium. After $17 \mathrm{~h}$ of copper or cadmium administration, the mycelia were washed 5 times with $200 \mathrm{~mL}$ of $10 \mathrm{mM}$ Tris-5 mM HCl buffer and collected from the medium by filtrating with filter paper and aspirator. The collected mycelia were homogenized in two volume of $100 \mathrm{mM}$ Tris-50 mM HCl buffer using a polytron, at about $20000 \mathrm{rpm}$ for 30 seconds 6 times and the disrupted mycelia were centrifuged at $13000 \mathrm{rpm}$ for $1 \mathrm{~h}$. The supernatant was applied to a Sephadex G-50 $(5 \mathrm{~cm} \times 100 \mathrm{~cm}$ or $2.6 \mathrm{~cm} \times 100 \mathrm{~cm})$ gel filtration column equilibrated with $10 \mathrm{mM}$ Tris-5 mM HCl buffer, subsequently eluted with the same buffer, and fractions were collected.

\section{Spectroscopic analysis and metal determination}

The absorption spectra $(220 \mathrm{~nm}, 250 \mathrm{~nm}$ and $280 \mathrm{~nm})$ of the eluents in each fractions were determined with a Beckmann Spectrophotometer DU-65. Zinc and copper or cadmium concentrations were determined with a Hitachi flame atomic absorption spectrophotometer Model 180-30.

\section{Results and discussion}

\section{Properties of the copper-binding protein from the fungus}

When Beauveria bassiana was exposed to copper (1 mM), copper was incorporated and accumulated in the mycelia. The incorporated copper was eluted in low molecular weight region by the gel filtration, Sephadex G-50 in $10 \mathrm{mM}$ Tris$5 \mathrm{mM} \mathrm{HCl}$ (Fig. 1). The profile revealed the existence of a low molecular weight, copper-binding protein. Fractions of Peak A $(\mathrm{Kav}=0.5)$ were expected to MT containing fractions. From our previous study of amino acid composition analysis of the purified protein, the molecular weight of this protein was determined to be approximately $2400 \mathrm{Da}$. Amino acid composition of the purified copper-binding protein from the fractions of Peak A showed a cysteine-rich protein ( 5 cysteine residues in total of 22 amino acids) lacking aromatic amino acid residues [20-21] and shows very high similarity with metallothionein from Neurospora crassa and Agaricus bisporus [16-18].

The absorption spectrum with shoulder around $250 \mathrm{~nm}$ and $320 \mathrm{~nm}$ was typical of $\mathrm{Cu}(\mathrm{I})$-thiolate coordination. At neutral $\mathrm{pH}$, the protein had a distinct shoulder around $250 \mathrm{~nm}$, however, upon removal of copper by lowing the $\mathrm{pH}$ with hydrochloride $(\mathrm{HCl})$, the spectrum indicated a clear loss of the absorption shoulder. Furthermore, a copper-binding protein of the fungus Beauveria bassiana showed an orange luminescence with excitation at $300 \mathrm{~nm}$ and emission at $565 \mathrm{~nm}$ at $77 \mathrm{~K}$ [20-21]. It was known that $\mathrm{Cu}(\mathrm{I})$ MT shows a characteristic luminescence with an emission band in 500 to $650 \mathrm{~nm}$ by excitation in the ultraviolet region near $300 \mathrm{~nm}$ [19]. Similar luminescences have also been reported for $\mathrm{Cu}-\mathrm{MTs}$ from the fungus Neurospora crassa and Agaricus bisporus [23-24]. From these results, it was revealed the copper-binding protein from the fungus

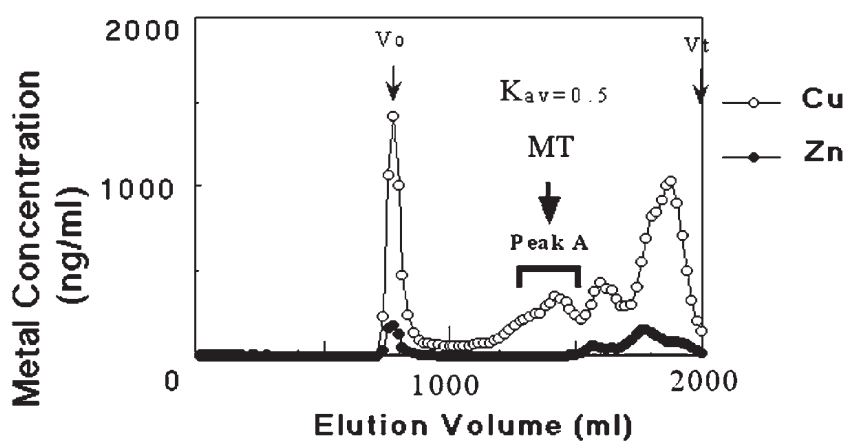

Figure 1. Elution profile of Sephadex G-50 gel filtration of supernatant from copper exposured mycelium of Beauveria bassiana. The chromatogram shows concentrations of $\mathrm{Cu}$ (open circle) and $\mathrm{Zn}$ (closed circle) in each fractions. Fractions of peak $\mathrm{A}$ were expected to MT fractions. 
Beauveria bassiana was a low molmolecular weight cysteine-rich protein lacking aromatic amino acid residues and may have copper-thiolate clusters structure in the molecule. From these properties, it was confirmed that the copperbinding protein from the fungus Beauveria bassiana was a class II type of Metallothioneins [5,20-21].

\section{Exposure of cadmium and properties of cadmium-binding protein from the fungus}

Upon exposure B. bassiana to cadmium (0.5 mM), cadmium was incorporated and accumulated in the mycelia. Incorporated cadmium was eluted in low molecular weight region by the gel filtration, Sephadex G-50 in $10 \mathrm{mM}$ Tris$5 \mathrm{mM} \mathrm{HCl}$ (Fig. 2). The value of Kav for the fractions of Peak A was approximately 0.5 . The elution profile of cadmium-binding protein showed very similar pattern to a copper-binding protein and revealed the existence of a low molecular weight, cadmium-binding protein. An elution profile of gel filtration from mycelia without supplement of metals as a control showed no cadmium containing fraction in the area of MT fractions (data not shown). It was elucidated that this cadmium-binding protein was induced by cadmium exposure. As shown in figure 3, the absorption spectra shows lack of $280 \mathrm{~nm}$ and have a shoulder around $250 \mathrm{~nm}$. At neutral $\mathrm{pH}$, the protein had a distinct shoulder around $250 \mathrm{~nm}$, however, upon removal of cadmium by acidification (addition of $\mathrm{HCl}$ ), the spectrum indicated a clear loss of the absorption shoulder (data not shown). This feature can be interpreted as a manifestation of the cadmium thiolate cluster structure in the molecules and the properties of absorption spectra lacking $280 \mathrm{~nm}$ showed a typical feature of metallothioneins.

It was previously reported that an ascomycete Neurospora crassa and a mushroom, basidiomycete, Agaricus bisporus induce copper-metallothioneins (Cu-MT) by copper exposure, however, no metallothioneins were induced in the

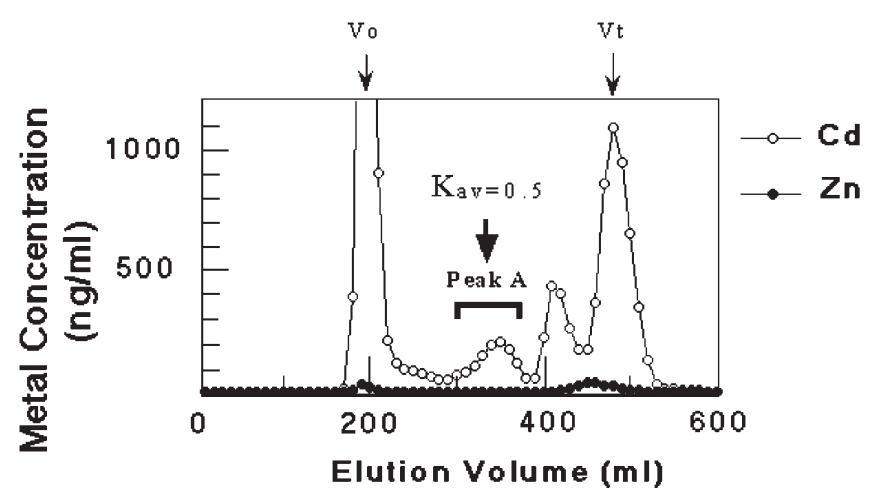

Figure 2. Elution profile of Sephadex G-50 gel filtration of supernatant from cadmium exposured mycelium of Beauveria bassiana. The chromatogram shows concentrations of $\mathrm{Cd}$ (open circle) and $\mathrm{Zn}$ (closed circle) in each fractions. Fractions of peak A were expected to MT fractions.

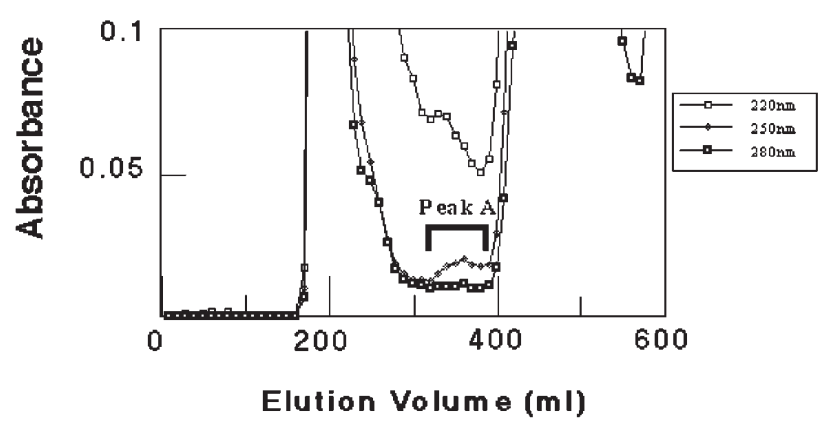

Figure 3. Absorbance of eluents of Sephadex G-50 gel filtration from cadmium exposured mycelium of Beauveria bassiana. The chromatogram shows absorption of $220 \mathrm{~nm}, 250 \mathrm{~nm}$ and $280 \mathrm{~nm}$ in each fractions. Fractions of peak A were expected to MT fractions.

fungus by cadmium or other heavy metals exposures [1618]. It was also reported that exposure of Candida glabrata to copper stimulates formation of MTs, whereas exposure to cadmium PC derivatives were synthesized [19]. On the other hand, in this study, it was indicated that exposure to cadmium may cause to induce a MT in the fungus $B$. bassiana. The protein may belong to class II type of MT which would be family 8 according to a new classification.

In conclusions, it was suggested a metallothionein could be induced in the fungus Beauveria bassiana by not only copper, but also cadmium exposure. It might be concerned with its heavy metal resistance in the further study.

\section{Acknowledgments}

The authors thank Prof. Dr. Jeremias. H. R. Kägi, Dr. Milan Vasak, Dr. Peter Hunziker, Biochemisches Institut der Universität Zürich, Switzerland, for helpful suggestions.

\section{References}

1. Kägi, J. H. R.; Vallée, B. L. J. Biol. Chem. 1960, 235, 34603465 .

2. Kojima, Y.; Berger, C.; Vallee, B. L.; Kägi, J. H. R. Proc. Natl. Sci. USA 1976, 73, 3413-3417.

3. Nordberg, G. F.; Nordberg, M.; Piscator, M.; Vesterberg, O. Biochem. J. 1972, 126(3), 491-498.

4. Kägi, J. H. R.; Kojima, Y. Exp. Supp. 1979, 34, 141-142.

5. Kojima, Y. Methods in Enzymol. 1991, 205, 8-10.

6. Kojima, Y.; Binz, P. A.; Kägi, J.H.R. In Metallothionein IV; Klaassen, C. D., Ed., Basel: Birkhaeuser Verlag, 1999; pp 36.

7. Binz, P. A.; Kägi, J. H. R. In In Metallothionein IV; Klaassen, C. D., Ed., Basel: Birkhaeuser Verlag, 1999; pp 7-13. 
8. Kägi, J. H. R.; Vasak, M.; Lerch, K.; Gilg, D. E. O.; Hunziker, P. E.; Berhard, W. R.; Good, M. Environ. Health Perspect. 1984, 54, 93-103.

9. Roesijadi, G.; Fowler, B. A. Methods in Enzymol. 1991, 205, 263-273.

10. Dallinger, R.; Berger, B.; Hunziker, P. E.; Kägi, J. H. R. Nature 1997, 388, 237-238.

11. Piscator, M. Nord. Hyg. Tidskr. 1964, 45, 76-82.

12. Nordberg, G. F. Environ. Physiol. 1971, 1, 171-187.

13. Nordberg, M. J. Trace. Elem. Exp. Med. 2000, 13, 97-104.

14. Kapoor, A. Bioresource Technol. 1995, 53(3), 195-206.

15. Mehra, R. K.; Tarbet, E. B.; Gray, W. R.; Winge, D. R. Proc. Natl. Acad. Sci. USA 1988, 85, 8815-8819.

16. Lerch, K. Nature 1980, 284, 368-370.

17. Beltramini, M.; Lerch, K. Biochemistry 1983, 22, 2043-2048.
18. Münger, K.; Lerch, K. Biochemistry 1985, 24, 6751-6756.

19. Mehra, R. K.; Winge, D. R. J. Cellul. Biochem. 1991, 45(1), 30-40.

20. Kameo, S.; Kojima, Y. Biomed. Res. Trace Elements 1996, 7(3), 47-48.

21. Kameo, S.; Faller, P.; Vasak, M.; Kojima, Y. In Metallothionein IV; Klaassen, C. D., Ed., Basel: Birkhaeuser Verlag, 1999; pp 207-212.

22. Stillman, M.; Gasyna, Z. Methods in Enzymol. 1991, 205, 540555.

23. Beltramini, M.; Lerch, K. FEBS Letters 1981, 127(2), 201203.

24. Beltramini, M.; Münger, K.; Germann, U. A.; Lerch, K. Experientia Suppl. 1987, 52, 237-241. 